\title{
Azospirillum brasilense and macronutrients in the initial establishment of brachiaria
}

\author{
Tauane Santos Brito*, Tatiane Eberling, Leila Alves Netto, Giovana Ritter, Renan Pan, Daniele Cristina \\ Schons Eckhardt and Vandeir Francisco Guimarães
}

State University of Western Paraná, Marechal Cândido Rondon, PR, Brazil. *Author for correspondence: tauane.brito@unioeste.br

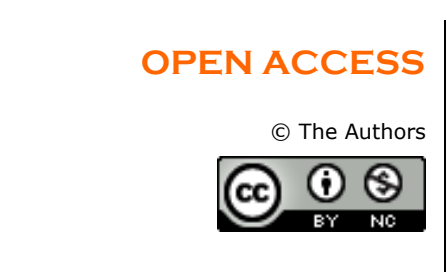

Submitted on June 29, 2019 Accepted on October 17, 2019 Early View on October 22, 2019 Final Publication on October 23, 2019 Authors declare no conflict of interest

KEYWORDS: Nitrogen

Phosphorus

Potassium

Pastures Growth promotion

\section{ABSTRACT}

Pasture production needs sustainable technologies, associating correct fertilization techniques that allow its maintenance aiming at productivity for quality animal feed production. The objective was to evaluate the initial responses of the inoculation with Azospirillum brasilense associated to macronutrients in Brachiaria brizantha cv. 'Xaraés'. In pots filled with Oxisoil, with combinations of macronutrients as formulates (10-10-10; 20-10$10 ; 10-20-10$; and 10-10-20) associated or not to inoculation with growth promoting bacteria A. brasilense, the experiment was conducted in a randomized blocks design, with four replicates. At 10, 20 and 30 days after emergence the plants were evaluated for number of leaves, length of the biggest leaf, aerial length, number of tillers and chlorophyll relative content. At 30 days after emergence, plants were evaluated for dry mass of roots and aerial part, root length, leaves content of nitrogen, phosphorus and potassium. The use of the formula 10-20-10, in the absence or presence of inoculation with $A$. brasilense, increased the leaves initial development of plants of $B$. brizantha cv. 'Xaraés'. The formula 10-10-10, in the absence and presence of bacterial inoculation, resulted in plants with lower foliar development up to 30 days after emergence.

\section{Highlighted Conclusions}

The nutritional availability influences in the initial development of seedlings of $B$. brizantha cv. 'Xaraés'.

\section{INTRODUCTION}

The cultivation of pastures in the Brazilian territory stands out due to the high demand from the cattle raising sector, especially in the Midwest (Dias et al. 2016). Brachiaria is a genus of Poaceae with herbaceous growth, native from Africa, introduced in Brazil as forages, but that can also be considered invasive plants in many ecosystems, especially in the Brazilian "cerrado" (Florindo et al. 2014). For the cattle raising sector, the brachiaria is a nutritive pasture, used in cattle feed, resulting in high quality animals, guaranteeing Brazil the position of the world's largest exporter of beef (Cezário et al. 2015, Peres et al. 2015, Dias et al. 2016).

Forages from the genus Brachiaria are used as a food source not only for cattle but also for buffaloes, sheep and goats due to its high forage production, fast and high regrowth capacity, and to its tolerance to adverse environmental conditions (cold, drought and fire), besides the persistence and late flowering (Florindo et al. 2014, Cezário et al. 2015). However, it has a high demand for fertile and drained soils, needing some regular fertilizations for the obtention of an average production of 21 tones of dry mass per hectare (Bonfim-Silva et al. 2014, Martins et al. 2014).

In the process of choice of a forage for the cattle raising farms, the speed of its development is essential. In rain or drought periods, plants from the genus Brachiaria have a high rates of growth and mean crude protein (Castro et al. 2013, Galzerano et al. 2013). Of average requirement, brachiarias are very responsive to doses of phosphorus, especially when managed with three cuts during its cycle, directly reflecting on the dry mass production, in especial under average conditions of rainfall and temperature (Castro et al. 2013, Oliveira et al. 2013).

In this sense, the use of organisms that optimize the use of both nutrients that are already on the soil as for the ones from inorganic or organic fertilization, stands out as a viable and sustainable alternative for these goals. Plant growth promoting bacteria are symbiont microorganisms capable of promoting growth through the nitrogen biologic 
fixation, solubilization of nutrients, production of phytohormones, among others (Guimarães et al. 2017). Among them, the bacteria Azospirillum brasilense stands out due to positive results when it was associated to grasses such as maize (Guimarães et al. 2014, Bulegon et al. 2017b), wheat (Fukami et al. 2016; Santos et al. 2017a), sugarcane (Santos et al. 2017b, Santos et al. 2019) and brachiaria (Bulegon et al. 2017a).

Using the inoculation with $A$. brasilense in Urochloa ruziziensis as an alternative to mitigate the damages caused by drought, Bulegon et al. (2017a) report that the inoculation influenced in the tolerance of this crop to the hydric stress, besides influencing in the increase of photosynthetic rates. Hungria et al. (2016) report that the use of A. brasilense together with the nitrogen fertilization of Brachiaria spp., in different regions of Brazil, resulted in inoculated plants with final nitrogen accumulation similar to the obtained in plants that received a second nitrogen fertilization ( $40 \mathrm{~kg} \mathrm{ha}^{-1}$ of $\mathrm{N}$ ) along its cycle.

In view of the foregoing, the hypothesis of this research is that the use of different doses of different formulas, with higher or lower availability of nitrogen, phosphorus and potassium, will reflect in the responses of the use of inoculation with plant growth promoting bacteria, responding in morphometric parameters along the plant development. Thus, the objective of this study was to evaluate the initial response of Brachiaria brizantha cv. 'Xaraés' to inoculation with Azospirillum brasilense associated to macronutrients.

\section{MATERIAL AND METHODS}

The experiment was conducted in a greenhouse, under the geographical coordinates $54^{\circ} 22^{\prime} \mathrm{W}, 24^{\circ} 46^{\prime} \mathrm{S}$, and altitude of $420 \mathrm{~m}$. The region climate is classified as Cfa mesothermic humid (Alvares et al. 2013).

Seeds of brachiaria from the specie B. brizantha cv. 'Xaraés', obtained from the local commerce, were inoculated with the commercial inoculant 'Nitro1000 gramineas' containing the plant growth promoting bacteria (PGPB) A. brasilense, strains Abv5 and Abv6, in the concentration of $2,0 \times 10^{8} \mathrm{CFU} \mathrm{mL}^{-1}$.

For the formulated production, it was used urea $\left(\mathrm{CH}_{4} \mathrm{~N}_{2} \mathrm{O}\right)$, super phosphate simple $\left(\mathrm{P}_{2} \mathrm{O}_{5}\right)$ and potassium chloride $(\mathrm{KCl})$ as source of nitrogen $(\mathrm{N})$, phosphorus $(\mathrm{P})$ and potassium $(\mathrm{K})$, respectively.

The experimental design used was of randomized blocks with a factorial scheme $2 \times 4$, with four replicates. The first factor constituted in the presence and absence of inoculation with the plant growth promoting bacteria Azospirillum brasilense. The second factor constituted in different formulates of fertilizers with nitrogen, phosphorus and potassium (10-10-10, 20-10-10, 10-20-10 and 10-10-20).

Seeds were inoculated in a laminar flux chamber, 30 minutes prior sowing, in the dose of $100 \mathrm{~mL}$ to each $25 \mathrm{~kg}$ of seeds. The experimental units constituted of 15 liters polyethylene pots, filled with $14 \mathrm{dm}^{3}$ of substrate. Sieved soil, from the experimental area, was used as substrate, being it characterized as an Oxisoil with clayey texture (Santos et al. 2013). It was chemically analyzed, presenting the following characteristics: $\mathrm{pH}\left(\mathrm{CaCl}_{2}\right)$ : 6.29 ; organic matter: $19.14 \mathrm{~g} \mathrm{dm}^{-3}$; $\mathrm{P}$ available (Mehlich $\left.{ }^{-1}\right): 32.55 \mathrm{mg} \mathrm{dm}^{-3} ; \mathrm{K}$ (Mehlich-1): $0.26 \mathrm{cmol}_{\mathrm{c} \mathrm{dm}}^{-3} ; \mathrm{Ca}^{2+}\left(\mathrm{KCl}^{1} \mathrm{~mol} \mathrm{~L}^{-1}\right)$ : $5.71 \mathrm{cmol}_{\mathrm{c} \mathrm{dm}}{ }^{-3} ; \mathrm{Mg}^{2+}\left(\mathrm{KCl} 1 \mathrm{~mol} \mathrm{~L}^{-1}\right): 3.29 \mathrm{cmol}_{\mathrm{c}} \mathrm{dm}^{-3} ; \mathrm{Al}^{3+}\left(\mathrm{KCl} 1 \mathrm{~mol} \mathrm{~L}^{-1}\right): 0.00 \mathrm{cmol}_{\mathrm{c} \mathrm{dm}}{ }^{-3} ; \mathrm{H}+\mathrm{Al}(\mathrm{pH}$ SMP 7.5$)$ : $3.36 \mathrm{cmol}_{\mathrm{c}} \mathrm{dm}^{-3}$; bases sum (BS): $9.22 \mathrm{cmol}_{\mathrm{c}} \mathrm{dm}^{-3}$; cation exchange capacity (CEC): $12.63 \mathrm{cmol}_{\mathrm{c}} \mathrm{dm}^{-3}$; bases saturation (V): $73.39 \%$.

In the sequence, six seeds of $B$. brizantha cv 'Xaraés' were sowed per pot, according to the pre-determined treatment, being they thinned at six days after emergence, leaving five plants per pot. Parallel to the implementation, the application of different fertilizers with nitrogen, phosphorus and potassium was made. The cultural managements were made according to the necessity.

The experiment was conducted for 40 days. From the tenth day, every 10 days the following non-destructive evaluations were made: number of leaves, length of the longest leave $(\mathrm{cm})$, number of tillers and SPAD index (Konica Minolta Plus 520).

At the end of the experiment were made the destructive analysis of root and aerial dry mass $(\mathrm{g})$, root length $(\mathrm{cm})$, foliar content of nitrogen, phosphorus and potassium, according to the methodology of Lana et al. (2016).

Data were tabulated and submitted to variance analysis. When significant compared by the Tukey test at $5 \%$ probability of error, for the macronutrient's comparison, and regression for the evolution along the periods. All analyses were made using the statistic software SISVAR (Ferreira 2014).

\section{RESULTS AND DISCUSSION}

Figure 1 presents the number of leaves of Brachiaria brizantha cv. 'Xaraés' in function of development periods, cultivated under different availabilities of macronutrients in the absence and presence of bacterial inoculation with Azospirillum brasilense. Plants fertilized with the formula 10-10-20, in the absence or presence of bacterial inoculation, presented regression curves in the polynomial model of the second order, with trend of development superior to the other treatments (Figure 1). 


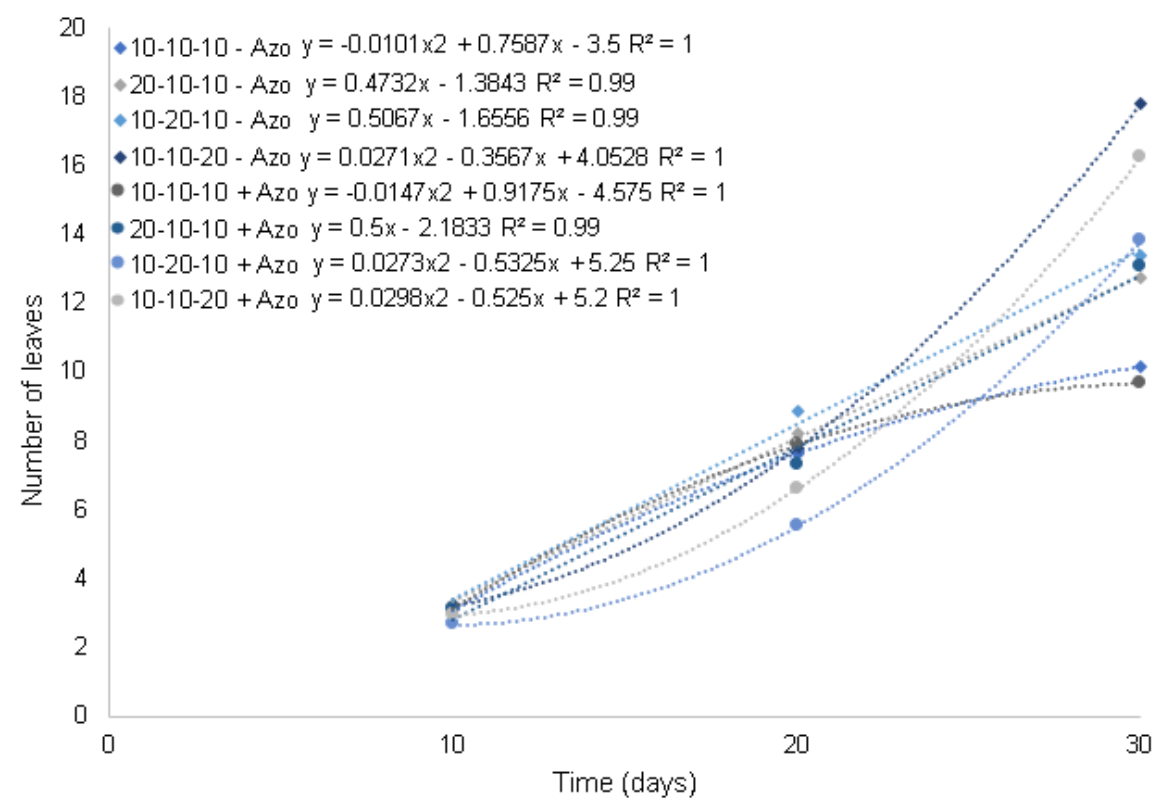

Figure 1. Number of leaves in plants of Brachiaria brizantha cv. 'Xaraés', at 10, 20 and 30 days after emergence, in function of fertilization with formulates in different proportions of macronutrients $(10-10-10 ; 20-10-10 ; 10-20-10$; and 10 10-20) in the presence (+ Azo) and absence (- Azo) of seed inoculation with Azospirillum brasilense.

At 30 days after emergence (DAE), non-inoculated plants and fertilized with the formula 10-10-20 presented average of 18 leaves per plant, while plants fertilized with the 10-10-10, in the presence and absence of inoculation with $A$. brasilense, presented average of 9 leaves per plant at 30 DAE. Plants fertilized with the formula 20-10-10 and 10-20-10 (Figure 1), in the presence and absence of inoculation, presented medium development in relation to the other regimen previously mentioned.

When choosing a pasture, the speed of leaf development is a decisive factor in the choice. Among many functions of the leaves in the plants is the realization of photosynthetic processes, which produce water, carbonic gas and sugars, using luminous energy collected by the photosynthetic pigments, being thus determinant the capacity of the luminous capture of these leaves in the photosynthesis (Taiz et al. 2014). In this sense, the number of healthy and photosynthetically active leaves is directly related to the photosynthetic potential of these pasture crops, guaranteeing the energy production for the recovery of organs removed due to pasture.

Comparing the development of $B$. brizantha cv. 'BRS' in full sun and shade with inoculation with Burkholderia pyrrocinia and Pseudomonas fluorescens, Lopes et al. (2018) mention that the use of bacterial coinoculation reflected on increase of the foliar area and in the SPAD index, independent of luminous availability. The use of coinoculation, in plants cultivated under plenty of sunlight, resulted in a better biomass production and in better photosynthetic performance than the non-inoculated, besides being an alternative as biofertilizers in forestry pasture due to the availability of light for growth to be limited (Lopes et al. 2018).

Figure 2 presents the length of leaves of $B$. brizantha cv. 'Xaraés' cultivated under different availabilities of macronutrients, in the absence and presence of bacterial inoculation with $A$. brasilense, in function of time. At 20 DAE, plants inoculated and fertilized with the formula 20-10-10 presented the highest averages, but they did not stand out at 30 DAE. Plants inoculated and fertilized with the formula 10-20-10 presented the smallest averages for the length of the biggest leaf at 20 days and stood out with higher averages at 30 days.

Plants fertilized with the formula 10-10-10, in the presence of $A$. brasilense, showed the smallest length of the biggest leaf at 30 days (Figure 2). Fertilization with the formula 10-10-20, in the absence and presence of $A$. brasilense, resulted in highest length of the biggest leaf. The cultivation of $U$. brizantha associated to $A$. brasilense under regime of four different doses of nitrogen, in two years of study, resulted in a $20 \%$ reduction in the need for nitrogen fertilization, increase in the forage production and mitigation of effects from hydric stress (Leite et al. 2019).

Studying three forages (Axonopus purpusii, Hymenachne amplexicaulis and Mesosetum chaseae) inoculated with Azospirillum, Souza et al. (2017) report that the inoculation of $A$. purpusii, H. amplexicaulis resulted in higher root volume and higher aerial dry mass, and that the inoculation of $M$. chaseae reflected in higher plant height, dry mass and root volume. 


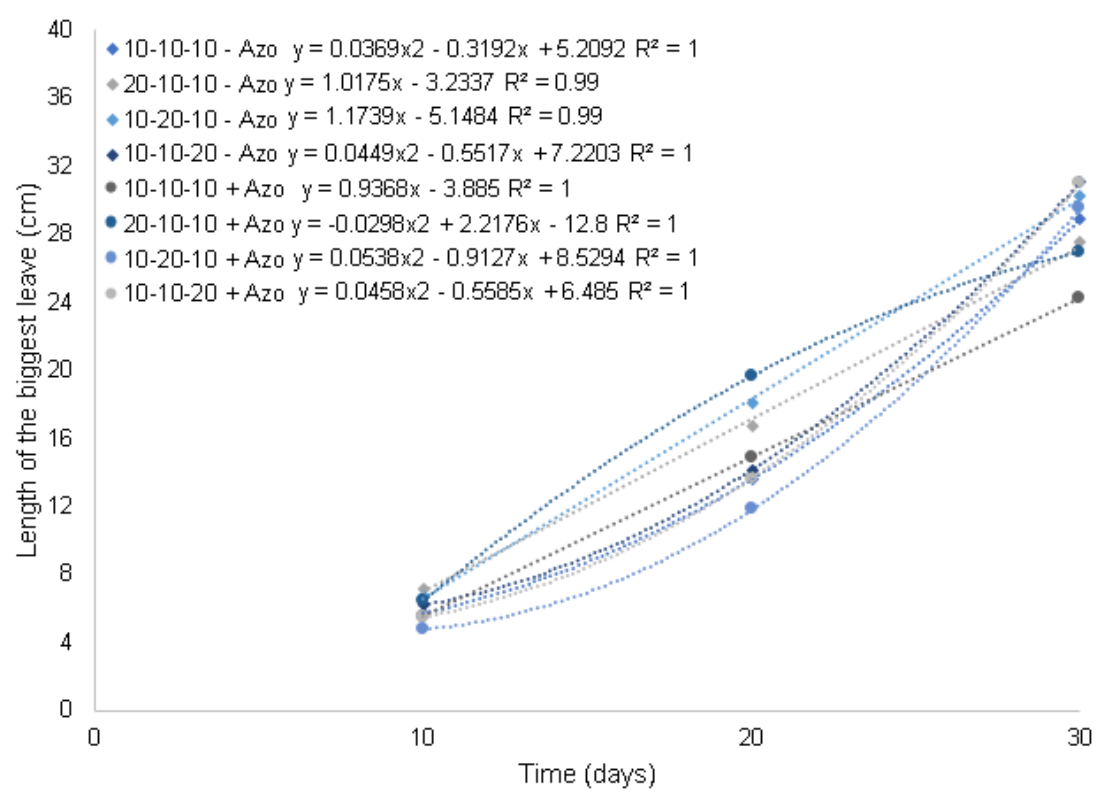

Figure 2. Length of the biggest leave in plants of Brachiaria brizantha cv. 'Xaraés', at 10, 20 and 30 days after emergence, in function of fertilization with formulates in different proportions of macronutrients $(10-10-10 ; 20-10-10 ; 10$ -

20-10; and 10-10-20) in the presence (+ Azo) and absence (- Azo) of seed inoculation with Azospirillum brasilense.

Figure 3 presents the plant height of $B$. brizantha cv. 'Xaraés' cultivated under different availability of macronutrients, in the absence and presence of inoculation with $A$. brasilense, in function of time. At 20 and 30 days, plants fertilized with the formula 10-20-10 presented greater averages for the parameter plant height. At 20 days, plants fertilized with the formula 10-20-10, independent of inoculation, presented the smallest averages (Figure 3).

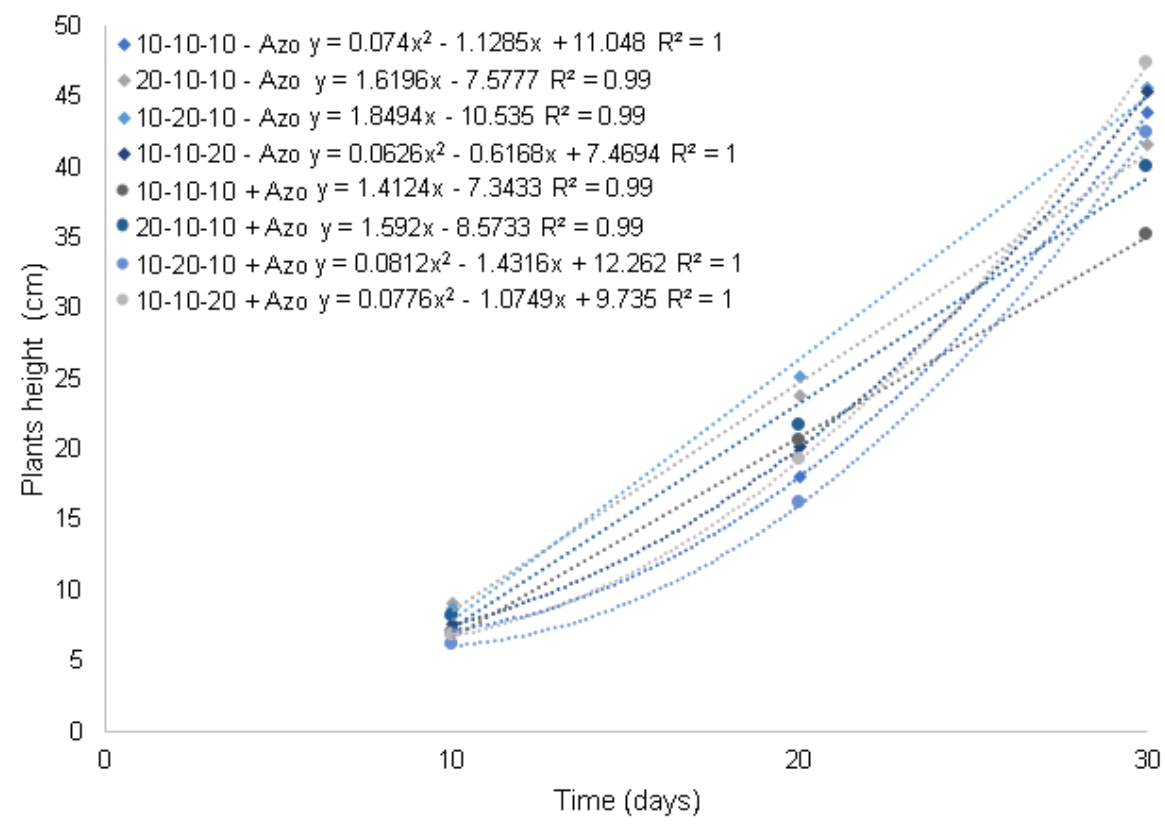

Figure 3. Plants height of plants of Brachiaria brizantha cv. 'Xaraés', at 10, 20 and $\mathbf{3 0}$ days after emergence, in function of fertilization with formulates in different proportions of macronutrients (10-10-10; 20-10-10; 10-20-10; and 10 10-20) in the presence (+ Azo) and absence (- Azo) of seed inoculation with Azospirillum brasilense.

Potassium solubilizing bacteria used together with stone powder in U. brizantha cv. 'Marandu' did not result in meaningful differences in the morphological parameters, such as width and length of leaves, density of tillers and dry mass. However, the stone powder promoted improvements in the bromatological properties, such as acid 
detergent fiber, hemicelluloses, dry mass digestibility, total digestible nutrients, digestible and metabolizable energy, contributing then to a nutritional enhancement, indicating the potential of this silicate rock as an alternative source to potassium chloride (KCl) (Miranda et al. 2018).

Figure 4 presents the SPAD index of plants of $B$. brizantha cv. 'Xaraés' cultivated under different availability of macronutrients, in the absence and presence of inoculation with $A$. brasilense, in function of time. The SPAD index was superior in plants inoculated and fertilized with the formula 20-10-10, being this fact predictable due to the higher availability of nitrogen of easy absorption in the soil, associated to the biological nitrogen fixation caused by the $A$. brasilense. But at 30 days, non-inoculated plants fertilized with the formula 20-10-10 presented the smallest averages, this fact may have occurred due to the high loss of nitrogen by volatilization, causing less significant effects in plants that had the nitrogen fixation bacteria as an alternative source of supply of this nutrient.

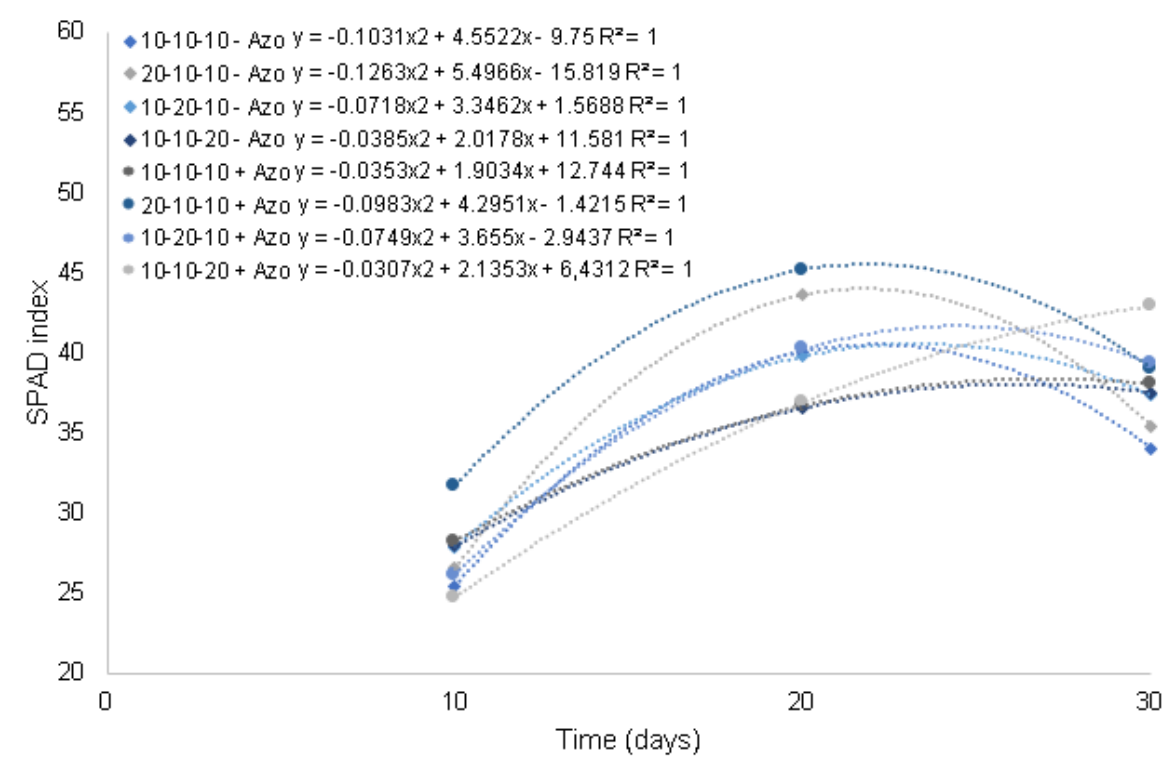

Figure 4. SPAD index of plants of Brachiaria brizantha cv. 'Xaraés', at 10, 20 and 30 days after emergence, in function of fertilization with formulates in different proportions of macronutrients (10-10-10; 20-10-10; 10-20-10; and 10 10-20) in the presence (+ Azo) and absence (- Azo) of seed inoculation with Azospirillum brasilense.

As mentioned in the parameter number of leaves, Lopes et al. (2018) comparing the development of $B$. brizantha cv. 'BRS' in different light availabilities, with inoculation with $B$. pyrrocinia and $P$. fluorescens, obtained that the bacterial coinoculation increase the SPAD index, independent of light availability. Testing the inoculation with strains from diazotrophic organisms and commercial inoculant based on Abv5 and Abv6 of $A$. brasilense in $B$. brizantha cv. 'Marandu' the authors report increase in the nitrogen content in the roots and in the aerial part, besides crude protein content in plants inoculated with diazotrophic strains (Guimarães et al. 2016).

In relation to the destructive analysis performed at the end of the experiment, no statistical difference was observed $(p<0.05)$ for the parameters root length ad foliar content of phosphorus and potassium. Figure 5 presents the number of tillers in plants of $B$. brizantha cv. 'Xaraés' cultivated under different availability of macronutrients, in the absence and presence of inoculation with $A$. brasilense, at 20 and 30 DAE. At 20 days, there was no statistical difference for the number of tillers. At 30 days, plants fertilized with the formula 10-10-20, in absence and presence of inoculation with $A$. brasilense, obtained higher averages on the number of tillers. Plants fertilized with the formula 10-10-10, independent of inoculation, presented the smallest averages (Figure 5).

Aiming to evaluate the forage production of Cynodon dactylon grasses, inoculated with $A$. brasilense, with nitrogen doses and different cutting regimes, Aguirre et al. (2018) report increases in the forage production when it was inoculated in the pasture implementation, even without nitrogen application, being unnecessary the reinoculation.

Figures 6 and 7 present the dry mass of roots and aerial part of plants of $B$. brizantha cv. 'Xaraés' cultivated under different availability of macronutrients, in the absence and presence of inoculation with $A$. brasilense, at 30 days after emergence. The aerial dry mass and root dry mass differed statistically only for the presence and absence of inoculation in the treatment 10-20-10, where the absence of inoculation resulted in higher averages (Figures 6 and 7). 

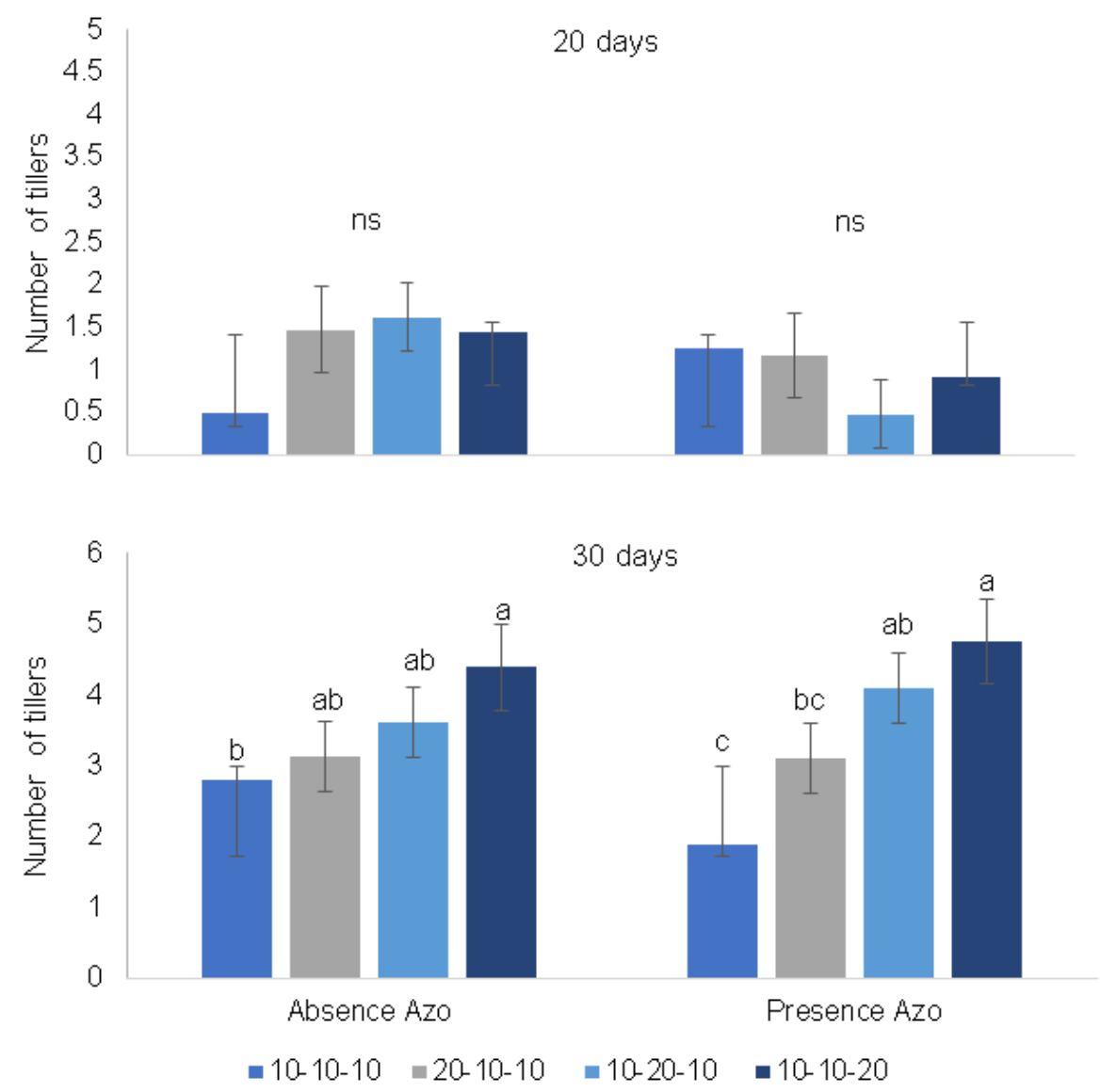

Figure 5. Number of tillers of plants of Brachiaria brizantha cv. 'Xaraés', at 20 and 30 days after emergence, in function of fertilization with formulates in different proportions of macronutrients (10-10-10; 20-10-10; 10-20-10; and 10 $10-20)$ in the presence (+ Azo) and absence (- Azo) of seed inoculation with Azospirillum brasilense.

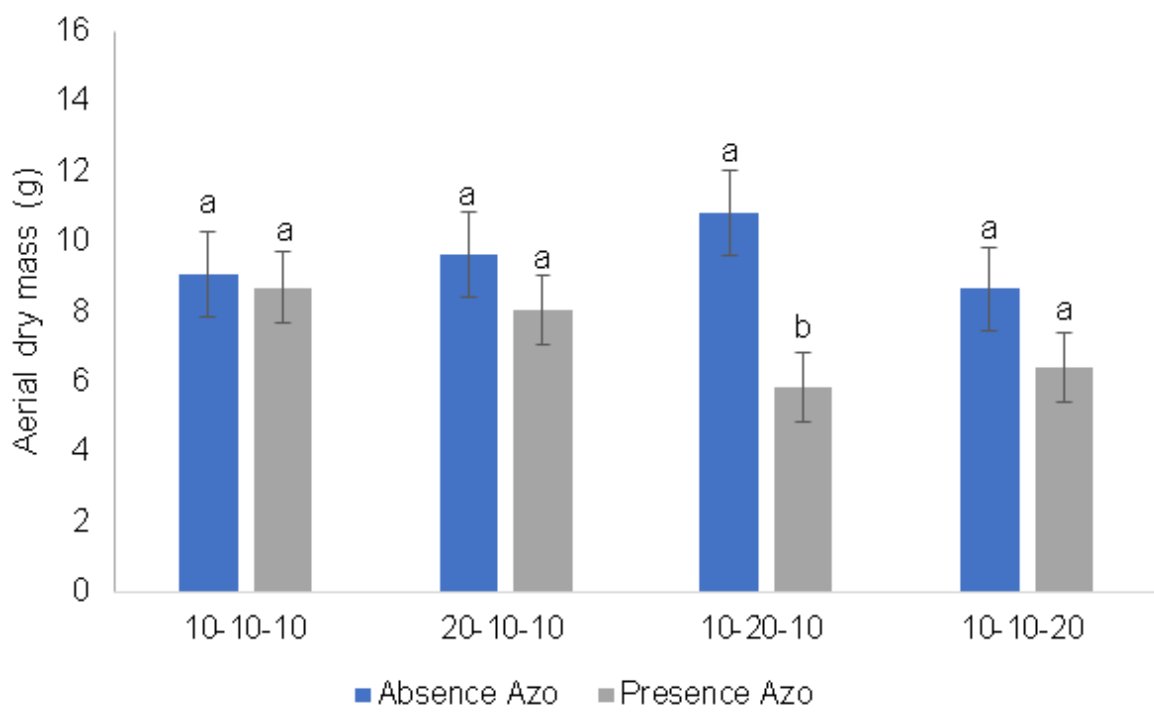

Figure 6. Aerial dry mass of plants of Brachiaria brizantha cv. 'Xaraés', at $\mathbf{3 0}$ days after emergence, in function of fertilization with formulates in different proportions of macronutrients (10-10-10; 20-10-10; 10-20-10; and 10-10-20)

in the presence (+ Azo) and absence (- Azo) of seed inoculation with Azospirillum brasilense.

Evaluating the diversity in vitro of bacteria associated to B. decumbens and B. humidicola, Oliveira et al. (2018) tested 20 diazotriphic isolates from the rizosphere, identified as Bacillus sp., Burkholderia sp., Enterobacter sp., Klebsiella sp., Microbacterium sp., Pantoea sp., Ralstonia sp., Rhizobium sp., Sinomonas sp., and Sphingomonas 
sp., and except the genus Rhizobium sp., all organisms present capacity to produce indoleacetic acid in the presence of tryptophan, and $60 \%$ produced indoleacetic acid independent of tryptophan. From all the microorganisms evaluated, $70 \%$ solubilize phosphate, $30 \%$ produced cellulase, $15 \%$ produced polygalacturonates and $30 \%$ produced amylase. The authors concluded that the characteristics obtained indicated that the association of pastures with bacteria with different growth promoting mechanisms may reflect in different responses to the plant development.

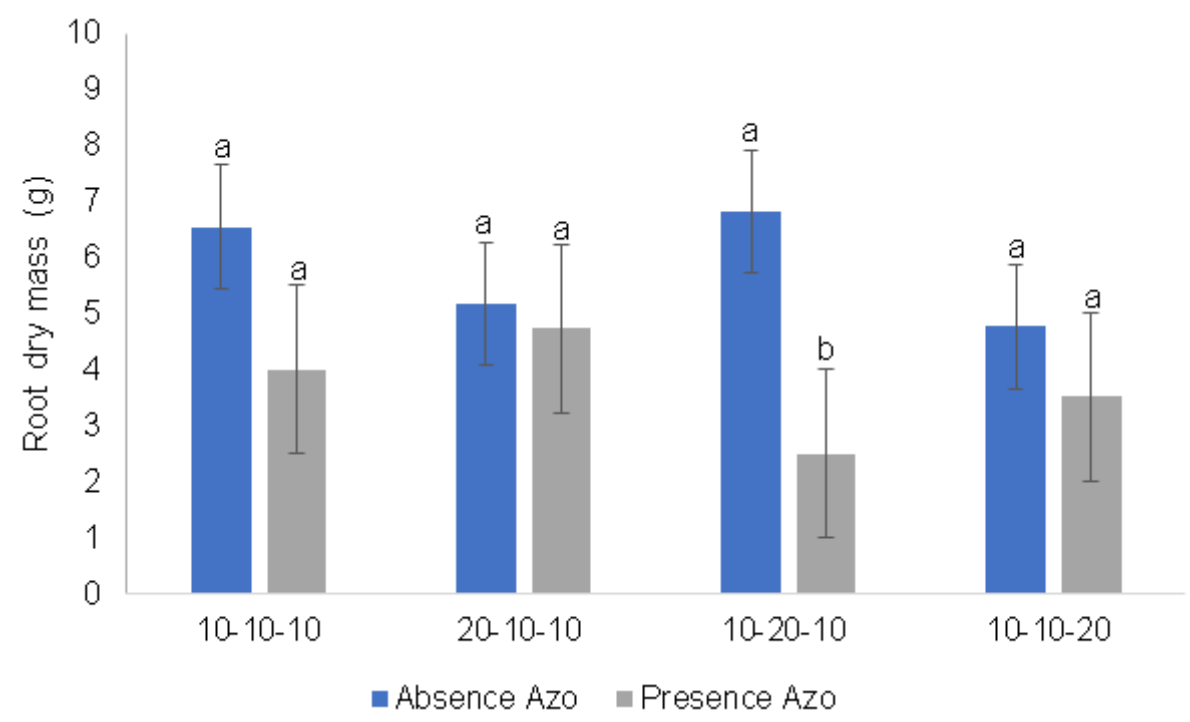

Figure 7. Root dry mass of plants of Brachiaria brizantha cv. 'Xaraés', at $\mathbf{3 0}$ days after emergence, in function of fertilization with formulates in different proportions of macronutrients (10-10-10; 20-10-10; 10-20-10; and 10-10-20)

in the presence (+ Azo) and absence (- Azo) of seed inoculation with Azospirillum brasilense.

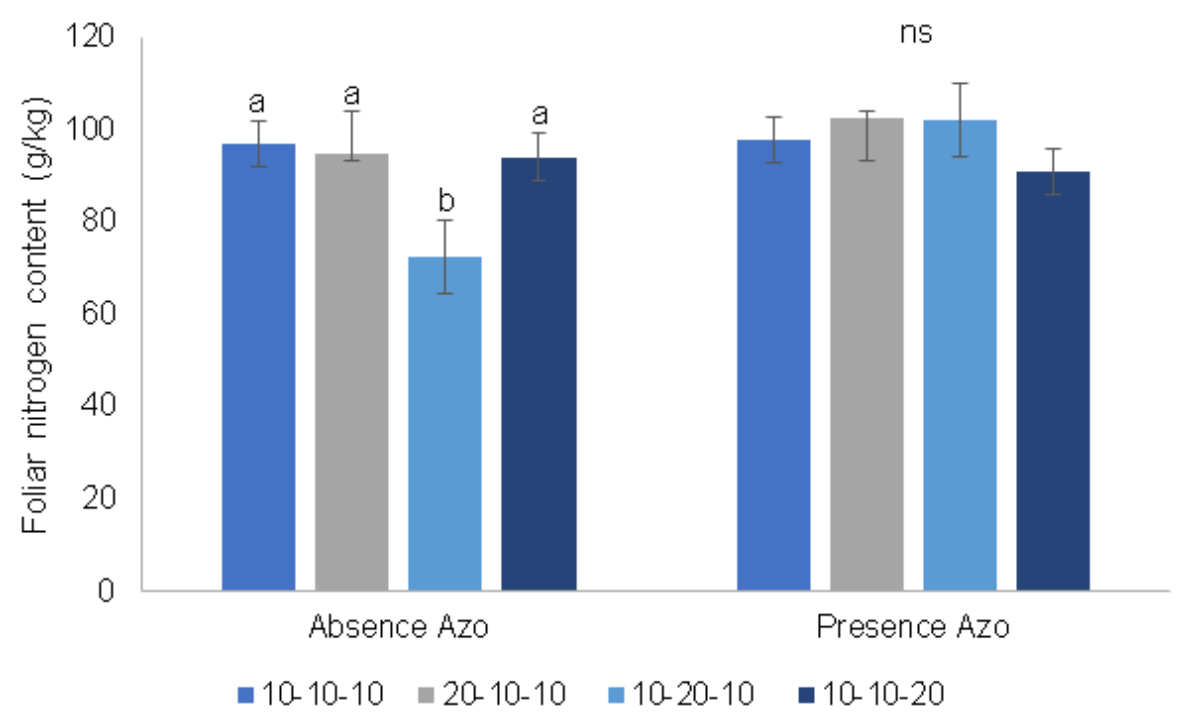

Figure 8. Foliar nitrogen content of plants of Brachiaria brizantha cv. 'Xaraés', at 30 days after emergence, in function of fertilization with formulates in different proportions of macronutrients $(10-10-10 ; 20-10-10 ; 10-20-10$; and 10 10-20) in the presence (+ Azo) and absence (- Azo) of seed inoculation with

Azospirillum brasilense.

These metabolites reported by Oliveira et al. (2018) are directly related to the characteristics of growth of plants. The indoleacetic acid is essential for plant growth, being one of the auxin sources that plants use in the root development and aerial development, reflecting in biomass production (Glick 2012). The solubilization of mineral phosphates is a very important characteristic in relation to the high demand of pastures for phosphorus (Oliveira et al. 2013). 
Figure 8 presents the foliar nitrogen content in plants of $B$. brizantha cv. 'Xaraés' cultivated under different availability of macronutrients, in the absence and presence of inoculation with $A$. brasilense. At 30 DAE there was difference only for non-inoculated plants, which fertilization 10-20-10 resulted in smaller averages of foliar nitrogen content.

The use of the formula 10-20-10, in the absence or presence of inoculation with $A$. brasilense, increased the leaves initial development of plants of $B$. brizantha cv. 'Xaraés'.

The formula 10-10-10, in the absence and presence of bacterial inoculation, resulted in plants with lower foliar development up to 30 days after emergence.

The nutritional availability influences in the initial development of seedlings of $B$. brizantha cv. 'Xaraés'.

\section{Acknowledgements}

To the 'Coordenação de Aperfeiçoamento de Pessoal de Nível Superior - CAPES' and to the post-graduation program in agronomy from the 'Universidade Estadual do Oeste do Paraná'.

\section{References}

Aguirre PF et al. 2018. Forage yield of Coastcross-1 pastures inoculated with Azospirillum brasilense. Acta Scientiarum. Animal Sciences 40:18.

Alvares CA et al. 2013. Köppen's climate classification map for Brazil. Meteorologische Zeitschrift. 22:711-728.

Bonfim-Silva EM et al. 2014. Concentration of nitrogen, phosphorus and potassium in tropical grasses fertilised with wood ash in cerrado oxisol. African Journal of Agricultural Research 9:549-555.

Bulegon LG et al. 2017a. Physiological responses of Urochloa ruziziensis inoculated with Azospirillum brasilense to severe drought and rehydration conditions. Australian Journal of Crop Science 11:1283-1289.

Bulegon LG et al. 2017b. Phytotoxicity of mesotriona in corn with Azospirillum brasilense associated nitrogen fertilization. Revista Brasileirade Ciencias Agrarias 12:325-331.

Castro LM et al. 2013. Forage production and structural composition of pastures of Xaraés grass managed in different grazing heights. Semina:Ciencias Agrarias 34:4145-4156.

Cezário AS et al. 2015. Silages of Brachiaria brizantha cv. Marandu harvested at two regrowth ages: Microbial inoculant responses in silage fermentation, ruminant digestion and beef cattle performance. Animal Feed Science and Technology 208:33-43.

Dias LCP et al. 2016. Patterns of land use, extensification, and intensification of Brazilian agriculture. Global Change Biology 22:2887-2903.

Ferreira DF. 2014. Sisvar: a guide for its bootstrap procedures in multiple comparisons. Ciencia e Agrotecnologia 38:109-112.

Florindo JB et al. 2014. Brachiaria species identification using imaging techniques based on fractal descriptors. Computers and Electronics in Agriculture 103:48-54.

Fukami J et al. 2016. Accessing inoculation methods of maize and wheat with Azospirillum brasilense. AMB Express 6:1-13.

Galzerano $L$ et al. 2013. Morphogenetic and structural characteristics of xaraés palisadegrass subjected to grazing intensities. Semina:Ciencias Agrarias 34:1879-1890.

Glick BR. 2012. Plant Growth-Promoting Bacteria: Mechanisms and Applications. Scientifica 2012:1-15.

Guimarães VF et al. 2014. Morphophysiological characteristics of maize inoculated with Azospirillum brasilense and Herbaspirillum seropedicae as seed treatment, cultivated in different types of soil. African Journal of Agricultural Research 9:2919-2924.

Guimarães SL et al. 2016. Nutritional characteristics of marandu grass (Brachiaria brizantha cv. marandu) subjected to inoculation with associative diazotrophic bacteria. African Journal of Microbiology Research 10:873-882.

Guimarães VF et al. 2017. Bactérias promotoras de crescimento vegetal: da FBN à regulação hormonal, possibilitando novas aplicações. In: Zambom MA et al. (Eds). Ciências agrárias: Ética do cuidado, legislação e tecnologia na agropecuária: Marechal Cândido Rondon, pp.193212.

Hungria M et al. 2016. Inoculation of Brachiaria spp. with the plant growth-promoting bacterium Azospirillum brasilense: An environment-friendly component in the reclamation of degraded pastures in the tropics. Agriculture, Ecosystems and Environment 221:125-131.

Lana MC et al. 2016. Análise química de solo e de tecido vegetal: metodologias analíticas. Edunioeste, Cascavel.

Leite RDC et al. 2019. Productivity increase, reduction of nitrogen fertiliser use and drought-stress mitigation by inoculation of Marandu grass (Urochloa brizantha) with Azospirillum brasilense. Crop and Pasture Science 70:61-67.

Lopes MJS et al. 2018. Light and plant growth-promoting rhizobacteria effects on Brachiaria brizantha growth and phenotypic plasticity to shade. Grass and Forage Science 73:493-499.

Martins LEC et al. 2014. Metabolic Change, Tillering and Root System of Brachiaria brizantha in Response To Phosphorus and Zinc Nutrition. Journal of Plant Nutrition 37:509-519.

Miranda CCB et al. 2018. Desenvolvimento de Urochloa brizantha adubada com fonolito e inoculada com bactérias diazotróficas solubilizadoras de potássio. Revista de Ciências Agrárias 41: 625-632.

Oliveira WL et al. 2013. Agronomic Traits, Morphogenetic and Structural Xaraés Grass Fertilized With Different Amounts of Phosphorus. Revista Brasileira de Agropecuária Sustentável 3:45-51.

Oliveira JTC et al. 2018. Diazotrophic bacteria isolated from Brachiaria spp.: genetic and physiological diversity. Ciencia e investigación agraria 45:277-289.

Peres AAC et al. 2015. Financial analysis of production systems for heifers on Brachiaria brizantha "Xaraés" pasture supplemented with mineral mixture. Archivos de Zootecnia 64:123-130.

Santos HG dos et al. 2013. Sistema Brasileiro de Classificação de Solos. In: Santos HG dos et al. (Eds). Embrapa, Brasilia. pp.1-286.

Santos KFDN et al. 2017a. Wheat colonization by an Azospirillum brasilense ammonium-excreting strain reveals upregulation of nitrogenase and superior plant growth promotion. Plant and Soil 415:245-255.

Santos SG et al. 2017b. Development and nitrate reductase activity of sugarcane inoculated with five diazotrophic strains. Archives of Microbiology 199:863-873. 
Santos SG et al. 2019. Rooting and growth of pre-germinated sugarcane seedlings inoculated with diazotrophic bacteria. Applied Soil Ecology 133:12-23.

Souza MST et al. 2017. Azospirillum spp. from native forage grasses in Brazilian Pantanal floodplain: biodiversity and plant growth promotion potential. World Journal of Microbiology and Biotechnology 33:1-13.

Taiz L et al. 2014. Plant Physiology and Development. Oxford University Press: Los Angels. 